\title{
Paul Masson-Oursel (1882-1956): Inside and Outside the Academy
}

\begin{abstract}
Paul Masson-Oursel (1882-1956) was a French Indologist who held the position of director of studies in Indian religions from 1927 to 1953 at the École Pratique des Hautes Études in Paris. However, alongside his well-received academic publications, Masson-Oursel also published many articles on India in nonacademic periodicals, some of which are clearly associated with esoteric currents. In 1929 for instance, he wrote a report for the Gruppo di Ur titled "On the Role of Magic in Hindu Speculation" which was published in the periodical Krur, ${ }^{1}$ directed by the Italian esotericist Julius Evola (1898-1974). Furthermore, in its edition of March 15th, 1946 the periodical Spiritualité printed an article by Masson-Oursel entitled "Similarity between physics and psychology in Indian philosophy."2 This periodical was directed by Robert Linssen (1911-2004), a close disciple of spiritual spokesperson Jiddu Krishnamurti (1895-1986). In their journals, both Evola and Linssen approached India through spiritually engaged perspectives, which makes the presence of an academic such as Masson-Oursel in their columns somewhat surprising. In this article I will ask why he desired and saw it fit to publish in such periodicals.
\end{abstract}

\section{Introduction}

In Scholars and prophets: Sociology of India from France in the $19^{\text {th }}-20^{\text {th }}$ centuries, ${ }^{3}$ Roland Lardinois examines what he calls "the field of production of discourses on India." Throughout this book, Lardinois discusses the autonomy of scholarly activities within a field of production which was also composed of authors interested in India from a literary or spiritual perspective. He highlights

1 Paul Masson-Oursel, "Sul ruolo della magia nella speculazione indù," Introduzione alla Magia quale scienza dell'Io (Roma: Tilopa Editrice, 1929), 259-264. For a French translation, see Paul Masson-Oursel, "Sur le role de la magie dans la speculation hindoue," in Tous les écrits de Ur \& Krur (1927-1928-1929): Introduction à la Magie (1955) (Roma: Archè, 1986), 297-305.

2 Paul Masson-Oursel, "Identité de la physique et de la psychologie dans la philosophie indienne,” Spiritualité 9, no.16 (15 March 1946): 90-91.

3 Roland Lardinois, Scholars and Prophets: Sociology of India from France $19^{\text {th }}-20^{\text {th }}$ Centuries (New Delhi: Social Science Press, 2013). The book was first published in French in 2007, see Roland Lardinois, L'invention de l'Inde: Entre ésotérisme et science (Paris: CNRS Editions, 2007).

Ә Open Access. () 2021 Léo Bernard, published by De Gruyter. (cc) BY-NC-ND This work is licensed under a Creative Commons Attribution-NonCommercial-NoDerivatives 4.0 International License.

https://doi.org/10.1515/9783110664270-008 
the fluid borders and continuous exchange between what he called the "scholarly pole" and the "heteronomous pole" of the field, the non-hegemonic currents, composed of people without institutional affiliation. In the attempt to arrive at a more precise understanding of the relation between these two poles, Masson-Oursel represents an exemplary case study. Here, I intend to focus on the nuanced relation with non-hegemonic currents to which Masson-Oursel's work testifies with a view to bringing out both the common and diverging epistemic patterns crossing the broad field of the production of discourses on India at that time. What were the points of agreement? What were the bones of contention? Before presenting the structure of my work, allow me to clarify one point. According to my view, Masson-Oursel does not belong to the non-hegemonic currents because his academic position makes him a representative of the established scholarly pole, that is to say the hegemonic pole. However, and as my work will point out, MassonOursel may have held some perspectives towards Hindu studies which appear not to chime with what one can understand from standard scholarship. Then, instead of apprehending Masson-Oursel as a deviant scholar who is no longer part of the hegemonic pole, I prefer to perceive him as a facet of the academic and hegemonic pole, which is something more plural than consistent. With this precision in mind, I will first address Masson-Oursel's scholarly work, with special emphasis on his faith in comparative philosophy. After mentioning his interest in esoteric matters, his relations with non-hegemonic currents will be analysed and the common ground shared with these currents clarified. By the end of this article, MassonOursel's involvement in a periodical such as Spiritualité should begin to make sense while new light will also be cast on the orienting principles of his scholarly work.

\section{The Plan of a Lifetime: La philosophie comparée}

Paul Masson-Oursel had a background in philosophy. After following the classes of Henri Bergson (1859-1941), he received his bachelor's degree in 1901 and his agrégation in 1906. His principal mentor was Lucien Lévy-Bruhl (1857-1939), thanks to whom he became the subeditor of the Revue philosophique de la France et de l'étranger from 1918. After the death of Lévy-Bruhl, Masson-Oursel became the director of publications of the journal, a position he shared with Sorbonne Professor Émile Bréhier (1876-1952). Nevertheless, Masson-Oursel never restricted 
himself to a single subject. In his auto-obituary written in 1952, four years before his death, Masson-Oursel wrote:

My masters were Bergson in philosophy, Pierre Janet in psychology, Lévy-Bruhl, Durkheim and Mauss in sociology. I received the teachings of Alfred Foucher who, alongside Hellenism, introduced me to Indianism, and those of Sylvain Lévi who embodied total Indianism. However, I also wanted to do sociology with Chavannes in order to situated China relative to Greece and India. I started by studying Chinese logicians alongside Greek sophists. ${ }^{4}$

It then appears that Masson-Oursel was educated by the cream of French scholarly society in the human sciences. From philosophy to Oriental studies, by way of psychology, sociology and anthropology, Masson-Oursel was closely acquainted with the most renowned French scholars of his time, and his sound transdisciplinary academic education allowed him to develop a research program entitled La philosophie comparée - comparative philosophy. He set out his program for the first time in 1911 in an article entitled "Purpose and Method of Comparative Philosophy," published in the Revue de métaphysique et de morale. ${ }^{5}$ He inclusively identifies as philosophical all "views on the nature of reality and the situation of Man" 6 and seeks to compare the various philosophical views emanating from across the world. From his perspective, comparative philosophy is "the comparative study of philosophical ideas, to whatever civilization they might belong." He emphasises that "no one philosophy has the right to put itself forward as co-extensive with the human mind, but each, even the weakest, is of documentary value."8 Naturally, he is well aware that each philosophical system emerged from a very specific historical context, and he criticizes the hasty comparisons made during the nineteenth century which did not pay attention to the differences revealed by history. Nevertheless, he suggests that "certain identical gestures of the mind [. . . ] may well vary in shape, while being constant in nature," 9 such as "the conflict between reason and faith, as well as their reciprocal influence; the differentiation among several mental functions dedicated to knowledge, which are speculative or practical to

4 Quoted in Olivier Lacombe, "Paul Masson-Oursel (1882-1956)," in Ecole pratique des hautes études, Section des sciences religieuses, Annuaire 1957-1958 (Paris: Imprimerie Nationale, 1957), 19.

5 Paul Masson-Oursel, “Objet et méthode de la philosophie comparée," Revue de métaphysique et de morale 19, no. 4 (July 1911): 541-548.

6 Masson-Oursel, "Objet et méthode," 542.

7 Masson-Oursel, “Objet et méthode,” 541.

8 Masson-Oursel, “Objet et méthode,” 547.

9 Masson-Oursel, "Objet et méthode," 545. 
varying degrees; the admittance of several forms of reasoning." ${ }^{10}$ For instance, he argues that "the situation in Islam of a peripatetic rationalism in confrontation with a free-spirited mysticism finds its counterpart in catholicity." 11 Through his comparative philosophy, Masson-Oursel sought to discover metaphysic laws overarching the diversity of philosophical ideas. It was his conviction that a comparative philosophy which consistently appeals to history, understood as a positive and rational undertaking, may well be considered an exact science. Masson-Oursel later devoted one of his doctoral dissertations, the one he considered as his "major" thesis, to comparative philosophy, the other was focused on Indian philosophy. ${ }^{12}$ Published in 1923, La philosophie comparée refined the research program first sketched in 1911. Masson-Oursel introduced his intention in the following terms: “The desire to expand, indeed to deepen one's knowledge through acquaintance with systems of thought other than those of the civilization to which one belongs, has been felt in diverse circles." ${ }^{33}$ Greek mysticism and the introduction of Indian Buddhism in Medieval China are called upon to illustrate his assertion, as well as Neoplatonism and Kabbalah. Yet he notices that "all the attempts to trace new ways" of those "speculative milieus", which "have established syncretism as a method," have only led to "impasses or false turns."14 "If the "perennis philosophia' was incessantly preached, hardly anyone thought to approach it by studying what Diogenes Laërtius called the "philosophy of the barbarians""15 states Masson-Oursel, and he regrets that "the disinterestedness of true science was lacking; as well as patience and method." 16 Masson-Oursel then explains his own method: influenced by Émile Durkheim (1858-1917), Lévy-Bruhl, to whom this book is devoted, and Auguste Comte (1798-1857), he emphasises the positivism of comparative philosophy and its solid foundation in the investigation of history. Philosophies are "materials as real as any other data. They exist in beliefs, oral traditions, written treatises"17 and can be grasped in history. Highlighting the example of philology, as well as anthropology and physiology, Masson-Oursel further advocates the use of the comparative method and, more precisely, of analogies, in philosophy. Nevertheless, he reduces his program to three civilisations: Europe,

10 Masson-Oursel, “Objet et méthode,” 545.

11 Masson-Oursel, "Objet et méthode," 544.

12 Paul Masson-Oursel, Esquisse d'une histoire de la philosophie indienne (Paris: Geuthner, 1923). It goes without saying that Masson-Oursel's work expanded beyond comparative philosophy.

13 Paul Masson-Oursel, La philosophie comparée (Paris: Alcan, 1923), 1.

14 Masson-Oursel, Philosophie comparée, 1-2.

15 Masson-Oursel, Philosophie comparée, 3.

16 Masson-Oursel, Philosophie comparée, 2.

17 Masson-Oursel, Philosophie comparée, 11. 
India and China. In conclusion, he asserts that the comparative method will allow for a proper understanding of religion and "compensate for the effect of desiccation for which erudite history is commonly reproached, a history which willingly loses sight of the human sense of events, institutions, customs and ideas." 18 In addition, after expressing caution over the distortive effect of theories and doctrines on our perception of reality, Masson-Oursel argues: "We have no chance of gaining access to this reality until we have systematically compared doctrines, to the extent that they neutralize each other to reveal the necessary, solid residue of pure experience. By so doing, perhaps we will find clear facts whose existence we hardly suspected." ${ }^{\text {"19 }}$ As examples of such facts, he cites levitation, telepathy, and above all, the experience of the absolute. According to him, "The experience of the absolute, denounced as the vainest of pretensions by the positivists, will perhaps appear to a positivism worthier of the name as a datum which we had misapprehended, as is so often the case, a datum which in any case harbours an incontestable truth content." 20 A similar set of objectives for comparative philosophy, orienting the approach of Masson-Oursel towards the occult, were also expressed in his review of a non-academic book - in which he participated - dealing with "the problem of fate." There, Masson-Oursel wrote: "We are of the conviction that to better understand the diverse ways in which these problems have been posed by human kind is the first condition for addressing them positively; it may sometimes even provide us with a means of solving them."21

The reception of Masson-Oursel's thesis is difficult to gauge. Given that comparative philosophy is nowadays an established sub-field of philosophy, one might expect La philosophie comparée to be considered a seminal work. An inquiry into the historiography of comparative philosophy, however, suggests otherwise. Other scholars are considered more seminal figures in the field, ${ }^{22}$ and even if, in 2005, a collective book devoted to comparative philosophy written by renowned French speaking philosophers acknowledged Masson-Oursel as the father of the term, his program was misread as lacking ambition. ${ }^{23}$ Such a misread is, for me, due to a lack of attention concerning Masson-Oursel's unconventional interests and personal perspectives that we shall now examine.

18 Masson-Oursel, Philosophie comparée, 195.

19 Masson-Oursel, Philosophie comparée, 185.

20 Masson-Oursel, Philosophie comparée, 186.

21 Paul Masson-Oursel, review of L'homme après la mort, by Fernand Divoire, Mercure de France (1 October 1927): 153.

22 Brajendranath Seal (1864-1938) and Charles A. Moore (1901-1967) mostly.

23 François Chenet, "Du sens de la philosophie comparée," in Philosophie comparée. Grèce, Inde, Chine ed. Johachim Lacrosse, (Paris: Vrin, 2005), 80. 


\section{Masson-Oursel off the Beaten Academic Track: His Interest in Esoteric Matters}

As mentioned in the intro, Masson-Oursel wrote several articles in different periodicals that I consider related to esoteric currents. Western esotericism, or simply esotericism, refers to an "umbrella term" 24 or more precisely a "historiographic category" 25 that covers a wide range of religious and philosophical currents. These currents vary from ancient Gnostic speculations to contemporary alchemy and include elements such as Christian Kabbalah and Illuminism, among others. As noticed by Henrik Bogdan and Olav Hammer in Western Esotericism in Scandinavia, "which substantive characteristics might unite such a disparate set remains an open and controversial issue," however, "considerably less controversy surrounds the question of what contents should be counted as part of the category of Western esotericism."26 These contents are for the most part gathered in the Dictionary of Gnosis \& Western Esotericism. ${ }^{27}$

Thus, Masson-Oursel wrote articles in esoteric periodicals such as Krur and Spiritualité. Both periodicals were very different in perspectives ${ }^{28}$ but shared common objectives. Spiritualité "sought to see the world regenerated by the spiritual transformation of the individual,"29 just as the Gruppo di Ur prompted its readers to "transform yourself." 30 Masson-Oursel wrote short texts concerning aspects of Hindu philosophies in these periodicals. Those aspects were of particular interest for the readers because they dealt mostly with magic, understood as "the human claim to act immediately on nature by means of states of consciousness

24 Wouter J. Hanegraaff, "Introduction," in Dictionary of Gnosis \& Western Esotericism, ed. Wouter J. Hanegraaff (Leiden: Brill, 2006), xi.

25 Egil Asprem, The Problem of Disenchantment: Scientific Naturalism and Esoteric Discourse 1900-1930 (Leiden: Brill, 2014), 8. On the construction of such a category see Wouter J.Hanegraaff, Esotericism and the Academy: Rejected Knowledge in Western Culture (Cambridge: Cambridge University Press, 2014).

26 Henrik Bogdan and Olav Hammer, "Introduction," in Western Esotericism in Scandinavia, ed. Henrik Bogdan and Olav Hammer, (Boston: Brill, 2016), 1.

27 Wouter J. Hanegraaff, ed., Dictionary of Gnosis \& Western Esotericism (Leiden: Brill, 2006). This publication tends however to focus on specific cultural areas (namely French, English, German and Italian) and to overlook others (such as Scandinavian).

28 Krur harshly criticized the theosophical movement, while Spiritualité, nearly twenty years later, was inscribed in this movement.

29 "Editorial," Spiritualité 8, no.1 (15 December 1944): 1.

30 “Aux lecteurs," in Julius Evola, UR \& KRUR “Introduction à la magie” UR 1927, trans. Gérard Boulanger (Milano: Archè, 1983), 4. 
or psychic operations." 31 My lack of expertise in the field of Hinduism does not allow me to enter into technical matters and to discuss in detail the content of Masson-Oursel's articles in esoteric periodicals. How particular Masson-Oursel's understanding of Hindu perspectives was is a question that I do not seek to answer here. As previously mentioned, my interest is rather focused on the reasons why Masson-Oursel accepted to publish in such periodicals, which could hold scholarly perspectives ${ }^{32}$ but were definitely not academic.

A first answer would be to assume feelings of sympathy on the behalf of Masson-Oursel for contents usually related to esotericism. This assumption is not ill-founded. Already in his thesis on comparative philosophy, Masson-Oursel sought to explain phenomena such as levitation, telepathy or the experience of the absolute. This can be directly related to his interest in psychical research which was attested to by his speech at the Institut Métapsychique International in 1951. ${ }^{33}$ Also, Masson-Oursel was drawn to astrology, to the point that he wrote a foreword for French astrologer André Barbault in 1961. ${ }^{34}$ Moreover, Mircea Eliade (1907-1986) detailed in his private diary his meeting with MassonOursel in March 1946 and described his apartment in this way: "On one shelf there were books about occultism, on another a skull, a Saint Sulpician lithograph, a horoscope." 35 Those interests were exacerbated toward the end of his life but did not appear all of a sudden at that time. However, to summarise Masson-Oursel's involvement in esoteric periodicals to an interest in esoteric matters is by far incomplete. A finer picture may emerge but only through an analysis of his complicated relationship with non-hegemonic currents, both related to esotericism and not.

The list of Masson-Oursel's relations with non-hegemonic currents is a long one. Masson-Oursel wrote numerous articles and papers in non-academic periodicals, some very similar to Spiritualite, ${ }^{36}$ as well as several forewords to books written by non-academic authors. An exhaustive representation of those publications, as useful as it may be, runs the risk of being muddled and

31 Masson-Oursel, "Sul ruolo della magia nella speculazione indù," 259.

32 Hans Thomas Hakl, "Julius Evola and the UR Group,” Aries 12, no.1 (2012): 53-90.

33 Paul Masson-Oursel, "Lumières de la Raison : Profondeurs de la Conscience," Revue Métapsychique, no.15 (July-August 1951): 97-98

34 Paul Masson-Oursel, foreword to De la psychanalyse à l'astrologie, by André Barbault, (Paris: Seuil, 1961), 7.

35 Mircea Eliade, Fragments d'un journal I, 1945-1969 (Paris: Gallimard, 1973), 20.

36 From 1949 on, he regularly published short articles in the periodical Harmonie edited by Jacques Demarquette (1888-1969), an active promoter of mysticism and interfaith dialogue. 
indigestible. ${ }^{37}$ I will thus adopt a selective approach and I will start by focussing on his disagreement with the perspective of René Guénon (1886-1951).

\section{His Relationship with René Guénon}

René Guénon is a well-known figure for scholars of Western esotericism. He is considered to be the father of the Traditionalist School, a current which, incidentally, deeply influenced other scholars of religion during the twentieth century. ${ }^{38}$ Raised in Blois, the young Guénon quickly integrated within the Parisian occultist milieu of La Belle Époque. His quarrel with Dr Gérard Encausse (1865-1916), also known as Papus, led him to join the Église Gnostique de France in 1908. According to David Bisson, this group furnished him with the three main elements of his doctrine: the concept of "Tradition" or a common heritage, guarded by a small elite, which predates revealed religions; the idea of an evil at work in the world; and the necessity of personal transformation in gaining access to original knowledge and combatting this evil. ${ }^{39}$ Of particular interest for present concerns is that Guénon first planned to have an academic career. He graduated in philosophy in 1916 and became a high-school professor of philosophy. However, his thesis in Indian studies was rejected in 1921 by the dean of the Sorbonne upon the recommendations of Sylvain Lévi (1863-1935). Concerning Guénon, Lévi wrote to the dean: "He intends to exclude all elements that do not correspond to his conception [. . .] everything is in the Vedanta [. . .] he shows little concern with history and historical criticism [. . . ] he is willing to believe in a mystical transmission of a primary truth revealed to the human genius from the first ages of the world. ${ }^{40}$ The premature

37 There are a few examples: Paul Masson-Oursel, "La Libération à l'indienne," Cahiers de l'Étoile, no.8 (May-June 1929): 405-416; Paul Masson-Oursel, "La méditation asiatique et la psychanalyse," Psyché, no.1 (November 1946): 68-70; Paul Masson-Oursel, "Le signe de l'homme," Le Signe de l'Homme, no.1 (October 1946): 8-9; Paul Masson-Oursel, “Comment l'Inde se représente l'âme humaine ou l'esprit humain,” Harmonie, no.1 (January 1949): 7-9; Paul Masson-Oursel, introduction to Amulettes, talismans \& pantacles by Jean Marquès-Rivière (Paris: Payot, 1950), 5-6; Paul Masson-Oursel, introduction to Le pressentiment chrétien dans les religions anciennes by Emile Lesimple (Paris: Adrien Maisonneuve, 1942), 7-8.

38 Mircea Eliade was one of them, as demonstrated by Mark Sedgwick in Mark Sedgwick, Against the Modern World: Traditionalism and the Secret Intellectual History of the Twentieth Century (Oxford-New York: Oxford University Press, 2004).

39 David Bisson, René Guénon: Une politique de l'esprit (Paris: Pierre-Guillaume de Roux, 2013), 31.

40 Jean-Pierre Laurant, René Guénon: Les enjeux d'une lecture (Paris: éditions Dervy, 2006), 109-110; Bisson, René Guénon, 46. It should be noted that this derogatory report ended with a 
end of Guénon's academic career did not prevent him from maintaining relations, however fraught, with a representative of the academy such as MassonOursel, who taught classes on Indian religions at the École Pratique from 1920. Both Guénon and Masson-Oursel knew each another well: they apparently took several courses jointly at the École Pratique and were both frequent visitors to the Musée Guimet in Paris, where many conferences on Indian civilization were held. Their relationship is well-documented thanks to a large body of letters exchanged between Guénon and Guido De Giorgio (1890-1957), an Italian esotericist closely tied to the aforementioned periodical Krur. De Giorgio also frequented the Musée Guimet, and evidently maintained some level of contact with Masson-Oursel since he had made the acquaintance of Guénon through him. The letter written by Guénon to De Giorgio on the $12^{\text {th }}$ of October 1924 gives us an insight into Guénon's perception of Masson-Oursel:

The opinion which you express of Masson-Oursel is in complete accordance with what I myself think of him. I do not believe that he is capable of seeing things otherwise; that is, other than through western eyes and through the prism of modern philosophy; we must not forget that, before he turned towards Oriental studies, he was trained in philosophy. Besides, he is too closely integrated into official circles, especially since he replaced Foucher at the Hautes Etudes; and I know that he also maintains relations with theosophists. ${ }^{41}$ He exhibits a tendency towards appeasing everyone and all opinions, a result no doubt of his quite indecisive character. ${ }^{42}$

Guénon presents here an incisive portrayal of the intermediary position of Masson-Oursel in the field of scholarship on India at that time. In Guénon's opinion, Masson-Oursel did not stand with him because he was too engaged in the academy. Moreover, he reproached Masson-Oursel for having adopted the

surprising recommendation that Guénon's thesis should be accepted: a recommendation, however, which was purely rhetorical in nature.

41 Although he was indeed close to several theosophists and accepted to have one of his conference papers published in a theosophical periodical in 1935, Masson-Oursel never minced his words when offering his assessment of the Theosophical Society, a major esoteric current, speaking of an "eclectic theosophy" in 1921 and of "a few international snobs" in 1960. See Paul Masson-Oursel, "La psychologie contemporaine et l'Intelligence de la Pensée Indienne," Revue Théosophique, no.4 (June 1935): 122-125; Paul Masson-Oursel, "Doctrines et méthodes psychologiques de l'Inde," Journal de psychologie normale et pathologique, (1921): 529; Paul Masson-Oursel, introduction to Disciplines, ritualisme et spiritualité by René Fouéré (Paris: éditions du vieux colombier, 1960), 9-10.

42 Correspondence from René Guénon to Guido De Giorgio, 12 October 1924, (unpublished letter, correspondance avec De Giorgio, non publié, 1924-1949 available on http://www.index-reneguenon.org), 2. 
standpoint of a Western philosopher on India. Guénon's criticism should be read as a response to Masson-Oursel's review of his book Introduction générale à l'étude des doctrines hindoues, the once rejected doctoral dissertation, in the periodical Scientia. Masson-Oursel here criticized Guénon’s “categorical condemnation of any attempt to explain what is metaphysical through the historical method." 43 At the same time however, he recognized in Guénon "the very rare virtue of judging the Hindu matter in an Indian way" and agreed with Guénon's conviction that "knowledge cannot compensate for understanding, and European criticism cannot dispense with initiation into indigenous traditions." 44 This stance allows us to understand another of Guénon's letters to De Giorgio, written on the $12^{\text {th }}$ of June 1927: "I recently saw Masson-Oursel, who said to me that he was drawing ever closer to my point of view and now recognizes that the orientalists had committed a great number of errors [. . .] He is really too indecisive and overly afraid of compromising himself by making clear affirmations in one direction or another." 45 A few months later however, in a review of Guénon's book Le Roi du monde, Masson-Oursel did choose his side:

Leibniz loved to say that there is gold in the smoke of scholasticism. It can probably be found - even among the alchemists - in the universal symbolism as set out by the Gnostics, the Hindus, the Chinese and the Kabbalists. Unfortunately, R Guénon does not seek to extract this gold; only critique may aspire to such an aim. He takes everything for valid currency, provided it be traditional in character, and does not doubt that everything corresponds to everything else. He thereby attests to the lineage of the symbolists. He possesses the knowledge; yet shows no caution in what he accepts. Critique would represent in his eyes a miserly undertaking, one which discredits the researcher, and entirely superfluous for an author who believes himself in possession of metaphysical truth. ${ }^{46}$

From 1927 onwards, the split between Guénon and Masson-Oursel seems to have been definitive. Guénon's contempt for the historical-critical method was too radical to be overlooked by Masson-Oursel whose criticism of Guénon's work chimed with that of Lévi concerning Guénon's doctoral dissertation. For a scholar, of course, attention to historical detail is an essential prerequisite;

43 Paul Masson-Oursel, review of Introduction générale à l'étude des doctrines hindoues, by René Guénon, Scientia 31 (1922), 411.

44 Masson-Oursel, review of Introduction générale à l'étude des doctrines hindoues, 411. This criticism is mentioned in Xavier Accart, Guénon ou le renversement des clartés (Milan: Archè, 2005), 201-202.

45 Correspondence from René Guénon to Guido De Giorgio published in Guido De Giorgio, L'Instant et l'Eternité (Milan: Archè, 1987), 263.

46 Paul Masson-Oursel, review of Le Roi du monde, by René Guénon, Revue critique d'histoire et de literature, no.20 (15 October 1927): 399. 
nevertheless, Masson-Oursel did maintain relations with several of Guénon's followers. On the $22^{\text {th }}$ of March 1947, for example, he lectured at the "Groupe d'Etudes des Techniques Mystiques et du Yoga," a group of non-scholars, for the most part physicians, primarily influenced by Guénon's ideas and seeking to study meditation techniques. ${ }^{47}$ Moreover, in an article written in 1953 in the highly reliable Revue philosophique de la France et de l'étranger, MassonOursel alluded to the possibility, through linguistic studies, of the recognition one day of a "primordial fund," shared by Asian and European civilizations, and Guénon, "who in thought took his bearings from Brahmanic teaching and in concrete life from the Islamic milieu," ${ }^{48}$ is credited as the main theorist of such a notion. The perspective of a "primordial fund" clearly appealed to Masson-Oursel and may explain his engagement with Guénon and those around him. He did, however, spell out that, to receive his full backing, this idea would need to be supported by scientific investigations. Masson-Oursel faced a wall which other authors not affiliated with the academy felt free to climb.

\section{His Influence in the Spread of Neo-Hinduism}

Another aspect of Masson-Oursel's mixed tangle of relationships is his engagement with actors in the field of Neo-Hinduism, both Hindu thinkers and their French translators. Neo-Hinduism is a term applied by Western scholars to Hindu thinkers who, in response to the challenges which emerged from the encounter with Western thought during the nineteenth and twentieth century, redefined "Hindu dharma as an essentially universal, ethical 'religion' (sādhārana dharma), based on principles of non-violence (ahimsā) and compassion." 49 Swami Vivekananda (1863-1902), Mohandas Karamchand Gandhi (1869-1948), Sri Aurobindo (1872-1950), and Sarvepalli Radhakrishnan (1888-1975) were all eminent Neo-Hinduism representatives. As a scholarly concept the term

47 For more on this group, better known as the "Winter Group" from the name of its main investigator, see Xavier Accart, “'Le Groupe Winter' entre perspective 'traditionnelle' et expérimentation médicale,” Politica Hermetica. Ésotérisme et guérison, no.18 (2005): 98-108. See also Accart, Guénon ou le renversement des clartés, 911-923.

48 Paul Masson-Oursel, “La connaissance scientifique de l'Asie en France depuis 1900 et les variétés de l'orientalisme," Revue philosophique de la France et de l'étranger (1953): 351.

49 William J. Johnson, “Neo-Hinduism," in A Dictionary of Hinduism (New-York: Oxford University Press, 2009), 220. 
"Neo-Hinduism" can of course be contested, and we will not seek here to address the question of the boundary delimiting the "Neos" as a group. 50 Following Wilhelm Halbfass (1940-2000), "Neo-Hinduism" is used as a convenient label to encompass the historical reality of India that is "the relatively unprepared opening to foreign, Western influences, the adoption of Western concepts and standards and the readiness to reinterpret traditional ideas in light of these new, imported and imposed models of thinking." 51 Such reinterpretations play a decisive political role in India, and also found fertile ground in the West and in France, especially through the popular publications of Romain Rolland (1866-1944). ${ }^{52}$ That Masson-Oursel played a part in this spread is a significant factor of his biography which deserves detailed treatment.

\section{His Acquaintance with the Ramakrishna Order}

In March 1936, the centenary of the birth of Ramakrishna (1836-1886), the renowned Bengali guru who promoted a vision of harmony between religions reinforced by his purported mystical experiences, was celebrated at the Musée Guimet. Some days later, the Institut de Civilisation indienne - the Institute of

50 The Indologist Paul Hacker (1913-1979) scholarly coined the concept during the 1970s to make a distinction between what he perceived as "traditional Hinduism" and this "novel Hinduism." The unmistakable contempt which Hacker showed towards Neo-Hinduism has led to much justified criticism, not least that of Wilhelm Halbfass himself. Let me make clear that there is no contempt intended in my use of the term Neo-Hinduism. See Paul Hacker, "Aspects of Neo-Hinduism as Contrasted with Surviving Traditional Hinduism," in Paul Hacker. Kleine Schriften ed. Lambert Schmithausen (Wiesbaden: Franz Steiner Verlag GMBH, 1978), 580-608; and Wilhelm Halbfass, Philology and Confrontation: Paul Hacker on Traditional and Modern Vedanta (Albany: State University of New York Press, 1995). For more recent and much harsher criticism of Hacker's work see Joydeep Bagchee and Vishwa P. Adluri, "The passion of Paul Hacker. Indology, orientalism, and evangelism," in Transcultural Encounters between Germany and India, ed. Joanne Miyang Cho, Eric Kurlander and Douglas T. McGetchin (New York: Routledge, 2014), 215-229.

51 Wilhelm Halbfass, "Research and Reflection: Responses to my Respondents," in Beyond Orientalism: The Work of Wilhelm Halbass and its Impact on Indian and Cross-Cultural Studies ed. Eli Franco and Karin Preisendanz, Poznan studies in the philosophy of the sciences and the humanities, vol. 59, (Amsterdam: Rodopi, 1997), 307.

52 Romain Rolland, Gandhi (Paris: Stock, 1924); Romain Rolland, Essai sur la mystique et l'action de l'Inde vivante (Paris: Stock, 1929); Romain Rolland, Vie de Ramakrishna (Paris: Stock, 1929); Romain Rolland, Vie de Vivekananda (Paris: Stock, 1930). 
Indian Civilization which belonged to the University of Paris and was located in the Sorbonne - also celebrated Vivekananda, Ramakrishna's disciple and founder of the Ramakrishna Order. Paul Masson-Oursel delivered a laudatory speech on both occasions. Those events may well have inspired an association named "Les Amis de la Pensée indienne" to send a letter to the headquarters of the Ramakrishna Order, requesting the dispatch of a permanent ambassador of the Order to France. The Swami Siddheswarananda (1897-1957) subsequently arrived in France in 1937 and succeeded in creating a French ashram, the Centre Védantique Ramakrishna, which still exists today. Masson-Oursel and the Swami were close friends and exchanged several letters. For instance, we learn in a letter sent by Masson-Oursel to the Swami on the $3^{\text {rd }}$ of April 1939 that the Swami followed the classes of Masson-Oursel at the École Pratique and that Masson-Oursel adapted the content of his teaching to the interests of the Swami, namely by addressing "the question of Yoga-Psychanalysis." 53 Moreover, a lecture delivered by Masson-Oursel at the Centre Védantique the $25^{\text {th }}$ of February 1940, on the occasion of the $105^{\text {th }}$ anniversary of Ramakrishna, provides much insight into Masson-Oursel's interest in Neo-Hinduism. It appears that Masson-Oursel actually devoted himself to the spiritual life and had a personal acquaintance with the spiritual teachings of Ramakrishna. During his address, he announces that:

I do not want to be a professor here, I will not speak as an academic, I would like, for once, to express only sincerity, because if I do not take the attitude of a modest disciple, I will have to flee like a wretch before this image [that of Ramakrishna] whose austere virtue reduces us to nothing as soon as we are anything other than sincere. ${ }^{54}$

Masson-Oursel then details his own spiritual life, quoting his favourite authors, from Seneca to Pierre Corneille by way of Epictetus, and expresses his own philosophical and spiritual beliefs:

The power that dominates me, but also invades me, what does it matter to me whether it is give this name or another? He is here, in me, and I am in him. That is enough, because that is all. There is something else in me than myself, and I am somewhere other than myself. [. . .] I am not locked in this miserable thing, Mr. X . . ., nothing more. [. . .] God and me, same thing. ${ }^{55}$

53 Correspondence from Paul Masson-Oursel to Swami Siddheswarananda (3 April 1939, unpublished letter transmitted to the author at the courtesy of Alejandro Gutierrez), $1 \mathrm{p}$.

54 Paul Masson-Oursel, "Lecture delivered by Mr Masson-Oursel for the 105th birthday of the birth of Ramakrishna” (25 February 1940, retranscription transmitted to the author at the courtesy of Alejandro Gutierrez), 1.

55 Masson-Oursel, "Lecture," 5. 
The professor even appears to claim for himself the status of spiritual teacher, or guru:

Academic training, which advocates the virtue of intelligence, objectivity, perhaps made me too timid to become a Guru. But Ramakrishna teaches us above all boldness. Let us repeat it: he was not a disciple of the great Goddess, Krishna, Civa, Yahweh, Jesus, Muhammad; he made himself Great Goddess, Krishna, Civa, Yahweh, Jesus, Muhammad!

In reflecting on this incredible, overwhelming adventure, let us remember the following teaching: the spiritual life consists in overcoming contradictions [. . .] We must not freeze before any of these contradictions. If you do not brave them, then you do not exist [ . . .]. ${ }^{56}$

Yet he regrets that he had enjoyed a "overly equable life" and adds: "What I probably missed was finding myself often enough in desperate conditions, I would have been more exalted."57 Finally, Masson-Oursel concludes his teaching by praying: "May Ramakrishna reminds us of what a man can achieve." 58 This address tells us much about his motivations and inner-conflicts: Masson-Oursel the academic, trained in historical criticism, but facing his own spiritual beliefs, his desire for the absolute, and trying to reconcile them with his professional agenda. In my opinion, this inner tension is the key which allows for a proper understanding of his relations with authors and periodicals approaching India through spiritual perspectives, and indeed of his scientific work.

\section{The Collection "Spiritualités Vivantes"}

The spiritual indebtedness of Masson-Oursel to Ramakrishna teachings explains his close relationship with Jean Herbert (1897-1980), who was the main French translator of the writings of Neo-Hinduism. In 1947, they created together, with the Albin Michel publishing house, a collection of books entitled Spiritualités vivantes, which proved to be a success still published today under its label. ${ }^{59}$ A leaflet of the collection Spiritualités vivantes and a letter,

56 Masson-Oursel, “Lecture," 5-6.

57 Masson-Oursel, "Lecture," 6. Unfortunately, Masson-Oursel spoke too fast as the Second World War would bring tragedy to his own life. As a member of the resistance, his eldest son disappeared after being caught by the Gestapo. Masson-Oursel himself spent time in captivity and returned severely traumatized. Later, in 1953, his wife passed away and the death of his younger son quickly followed. See Lacombe, “Paul Masson-Oursel (1882-1956),” 21.

58 Masson-Oursel, "Lecture," 7.

59 The collection is currently directed by Marc de Smedt and Jean Mouttapa, two people deeply involved in interfaith dialogue. The 2012 catalogue of Albin Michel made an inventory 
dated November 4, 1944, sent by Masson-Oursel to Henry Corbin (1903-1978), a renowned French Iranologist whose research centred upon Sufism and who participated in the Eranos meetings, are very informative sources regarding the aims of this collection. ${ }^{60}$ We learn that originally the collection was to be twofold: one part, directed by Herbert, devoted to the edition of "the original texts of contemporary thinkers enjoying incontestable authority among the religious, mystical or spiritual groups with which they are associated;"61 the second part, edited by Masson-Oursel, focusing on "studies made according to the methods of modern western science, and in a spirit of respectful sympathy by historians of spirituality, without regard given to country of origin."62 Its goals were thus ambitious. The editors hoped "to introduce among the spiritual elites around the world a wave of intense sympathy and warm understanding through which everyone will find themselves enriched,"63 and they had "high hopes the provision of Eastern resources to the West may prepare the advent of a more complete, more spiritually advanced man." ${ }^{64}$ During an interview accorded shortly before his death, ${ }^{65}$ Jean Herbert mentioned that, together with Masson-Oursel, he had already planned to create a collection on Hindus masters in 1937, but that it was in the wake of an article published in the periodical Les Cahiers $d u$ Sud that a contract was signed with Albin Michel in 1944. Indeed, a small controversy erupted between Masson-Oursel and Herbert during the Second World War. In an academic periodical, la Revue de l'histoire des religions, MassonOursel first criticized "French contemporary Indology." Indology of the day had up to then seen only "sporadic and very limited results" and Masson-Oursel himself was trying to address this lacuna. He asserts that "Indology cannot depend, as formerly it has done, solely upon the linguists." 67

of 267 books published in the collection, although most of them were published from 1970s onwards when the collection came to be issued in pocket format.

60 Correspondence from Paul Masson-Oursel to Henry Corbin, including a prospectus for the collection Spiritualités vivantes (4 November 1944, 5 COR 273, Henry and Stella Corbin fonds, École Pratique des Hautes Études Manuscripts and Archives - Religious Sciences section, Paris, France).

61 Prospectus for the collection Spiritualités vivantes.

62 Prospectus for the collection Spiritualités vivantes.

63 Prospectus for the collection Spiritualités vivantes.

64 Prospectus for the collection Spiritualités vivantes.

65 Jean Herbert, "Orient de l'âme. Entretien avec Jean Herbert," interview by Nouvelles Clés, Nouvelles Clés 22 (1992): 19-28.

66 Paul Masson-Oursel, "L’Indianisme français contemporain," Revue de l'histoire des religions 126 (1943): 57-62.

67 Masson-Oursel, “L’Indianisme,” 58. 
Indologist should "seek a meaning, a religious value, in those old texts, which are nearly all religious." 68 There is no room for "specialists with bounded horizons,"69 neither for "naïve enthusiasts."70 Masson-Oursel recommends a synthetic as well as analytic investigation and calls for "monographs which combine history and geography on every aspect and period of Indianness"71 in addition to "the joint work of the Pandits and the Europeans." "72 Herbert reviewed this article in a non-academic periodical, a literary journal named Les Cahiers du Sud, in 1944, where he agrees with Masson-Oursel's assessment and adopts a similarly critical stance towards contemporary Indology. ${ }^{73}$ He nevertheless criticizes the proposed remedy: Masson-Oursel, whose synthetic mind and encyclopaedic knowledge are praised, is exhorted to go further, to surpass his "inveterate humility." In Herbert opinion, scholars should not get lost in historical research or "dwell at length on apparent divergences of detail."74 They should rather "introduce India to the West."75 To be properly understood, India should be perceived "in its most beautiful heights, in the most beautiful contributions it has made to the common treasure of humanity, ${ }^{, 76}$ which is to say, in Herbert's mind, its spiritual writings. "To penetrate to the truth of an idea and to live one's life in accordance with it is much more important than to look for its distant origins" 77 and scholars should work to fathom Hindu spiritual ideas. The goals of the twofold collection Spiritualités vivantes then appears very clear. It was designed to meet the same challenge of cultivating a deeper understanding of India in the West through two different approaches: the first was academic, promoted by MassonOursel, and concerns the furtherance of comparative and historical studies; unlike the second, promoted by Jean Herbert, which relates to the translation and diffusion of spiritual writings. Spiritualités vivantes, whose section devoted to spiritual writings was first intended to embrace four different collections relating to Hinduism, Buddhism, Islamism and Taoism, is illustrative of the collaboration between non-hegemonic currents and representatives of the academy in the

68 Masson-Oursel, "L’Indianisme," 59.

69 Masson-Oursel, "L’Indianisme," 58.

70 Masson-Oursel, “L’Indianisme,” 61.

71 Masson-Oursel, "L'Indianisme," 62.

72 Masson-Oursel, "L’Indianisme,” 62.

73 Jean Herbert, "La Mission de l'Indianisme Français,” Les Cahiers du Sud (1 April 1944): 304-306.

74 Herbert, "La Mission," 305.

75 Herbert, "La Mission,” 304.

76 Herbert, "La Mission,” 305.

77 Herbert, "La Mission,” 305. 
sciences of religion. ${ }^{78}$ More broadly, the scope of diffusion of Neo-Hinduism in France attests to the depth of relations between these two poles, which should evidently not be framed in dualistic terms.

\section{Neo-Hinduism from the Theosophical Society to the Academy}

The case of Jean Herbert exemplifies the difficulties involved in separating the academic from the non-academic when it concerns Neo-Hinduism. I mentioned above Sarvepalli Radhakrishnan and Sri Aurobindo as two eminent NeoHinduism representatives: somewhat confusingly, the former was a university lecturer in philosophy, ${ }^{79}$ who exercised a considerable and direct influence over the field of comparative philosophy, while conversely the latter is considered to be a mystic and spiritual leader. Similarly, Herbert was as close to the Theosophical Society as the academy. He lectured at the Theosophical Society and wrote several articles in the theosophical periodical, Le Lotus bleu. ${ }^{80}$ One article, particularly long and rich, harshly criticizes a collective book written by established scholars: the first volume of L'Inde classique by Louis Renou (1896-1966) and Jean Filliozat (1906-1982). ${ }^{81}$ As an adept and translator of Neo-Hindu writings, it is hardly surprising to find Herbert associated with the Theosophical Society which is itself historically entangled with NeoHinduism. ${ }^{82}$ Meanwhile, it should be noted concerning Herbert that he ended

78 The success of this collaboration should, however, be qualified. I found no record of academic comparative studies published in the collection, which gave prominence rather to the translation of spiritual writings.

79 As well as President of India from 1962 to 1967 by the way.

80 Jean Herbert, "Notes sur la Philosophie contemporaine de l'Inde," Le Lotus bleu 49, no.2 (April 1938): 33-49; Jean Herbert, “Indianisme d'après-guerre en Sorbonne," Le Lotus bleu 55, no. 9-10 (November-December 1950): 359-376

81 Jean Filliozat and Louis Renou, L'Inde classique: Manuel des études indiennes (Paris: Payot, 1947).

82 On those reciprocal influences see Ulrich Harlass, "Another Neo-Hinduism? The Reception of Theosophy in the South Indian Journal the Siddhanta Deepika," Journal of Hindu Studies 10, no.2 (2017): 164-186.

For an overview of the Theosophical Society, see James A. Santucci, "Theosophical Society", in Dictionary of Gnosis \& Western Esotericism, ed. Wouter J. Hanegraaff (Leiden: Brill, 2006), 1114-1123. See also Gauri Viswanathan, “Theosophical Society,” in Brill's Encyclopedia of Hinduism, vol. 5, ed. Knut A. Jacobsen et al. (Leiden: Brill, 2013), 678-688. 
his career as a representative of the academy, to be exact as a privat-docent at the University of Geneva from 1955 to 1964 in charge of a classes on "Oriental Mythologies." 83 Regardless, Herbert, a brilliant interpreter, did not come to Oriental studies through philological studies but through his personal encounter with Sri Aurobindo, who granted him permission to translate his writings, in 1934. Another figure situated somewhere between Neo-Hinduism, the Theosophical Society and the academy is Gabriel Monod-Herzen (1899-1983). Monod-Herzen was an important French member of the Theosophical Society who also spread the teachings of Sri Aurobindo in France. Notably, he published a book on Sri Aurobindo in $1954 .{ }^{84}$ As to his relation with the academy, an unpublished letter addressed by the already mentioned Louis Renou, a French philologist and director of the Institute of Indian Civilization, to Masson-Oursel is instructive. In this letter, dated the $17^{\text {th }}$ of February 1950, we learn that Monod-Herzen was preparing a thesis on Sri Aurobindo, and that while Renou had accepted the idea of such a thesis four years before, he had decided to withdraw his support because Monod-Herzen's attitude toward academic Indology was too hostile and abusive. He refused to be part of the exam board, and it is my guess that Masson-Oursel was the thesis supervisor. This letter evidently did have an impact, as I have found no record of any thesis completed by Monod-Herzen. It would have been rejected as Guénon's thesis had been rejected by the dean of the Sorbonne thirty years ago. Louis Renou addresses Monod-Herzen in disparaging terms:

$\mathrm{M}-\mathrm{H}$. belongs to that group of people who believe themselves capable of attacking 'official' or 'academic' orientalism by appealing to living traditions and to the revelations which they have received from this or that contemporary mystic. There were people of this kind, well forgotten today, in the time of Burnouf and St Julian. There was Guénon, who Claudel considered to be the greatest living orientalist from the time of S. Lévi (and whose work still casts a shadow) There is now M.-H. and Jean Herbert (the recent book of the latter, 'Indian Spirituality' is no more than a long, vicious polemic against all the work which has been done in our domain). What would these pygmies know if there had not been the likes of Champollion, Burnouf, Colebrooke at the dawn of our studies? ${ }^{85}$

Nevertheless, after reading this letter we must not conclude that Louis Renou, as a philologist, was opposed to all modern interpretations of Hinduism. Rolland

83 Paul Servais, “Jean Herbert (1897-1980) et l'art de la traduction” in Passeurs de religions entre Orient et Occident ed. Jacques Scheuer and Paul Servais, (Louvain-la-Neuve: BruylantAcademia, 2004), 193-203.

84 Gabriel Monod-Herzen, Shri Aurobindo (Paris: Les Cahiers du Sud, 1954).

85 Correspondence from Louis Renou to Paul Masson-Oursel (17 February 1950, Paul MassonOursel file, documents waiting for inventory, Sorbonne Interuniversity Library Archives, Paris, France). 
Lardinois's distinction between a more conservative faction of the "scholarly pole" composed of philologists set apart from a more recent and open-minded side represented by philosophers such as Masson-Oursel should be qualified in light of Renou's privately expressed spiritual perspectives. ${ }^{86}$ Indeed, Louis Renou also participated in the spread of Neo-Hinduism and was closely connected with the Swami Siddheswarananda. They exchanged several letters which were published in a book written by Ms Maud Lallement, a French disciple of the Ramakrishna Order. ${ }^{87}$ In those letters, we learn that Renou was interested in Swami's translations from Sanskrit and was glad that the Swami had acknowledged his dependence on scholarly critical methods. Moreover, in a letter dated the $13^{\text {th }}$ December of 1943, Renou addressed the Swami in the following terms: "your goal is not to situate historically the doctrines in which you deeply hold faith, rather through these doctrines to establish standards which are valid for our time." 88 He further asserts:

I wish only that you be more economical still with your appeals to ancient sources, and that you come to elaborate a technique for approaching the divine to which all humanity may subscribe, one which overarches all religion and national doctrine. I am of the opinion that you are capable of succeeding in such an endeavour.

This does not prevent you from being of service to our studies in a more modest way by allowing them to benefit from the experience which you acquired through direct contact with India. The war having ended, I am entirely ready to open the doors of our institution so that you may address our little group of students on those doctrines that you have mastered, as it were, from the inside. ${ }^{89}$

Through the intervention of Renou, Swami Siddheswarananda actually gave lectures on Upanishadic thought at the Sorbonne each week. He was greeted in the Institute on the $26^{\text {th }}$ of June 1947 by two welcome addresses delivered by Alfred Foucher (1865-1952) and Masson-Oursel. ${ }^{90}$ Soon after the beginning of the First Indochina War, Foucher warned that "an immense task presents itself to your generation" that of reconciling "the West and the East, those two brothers so closely twinned by geography and history, who have become enemies." He praised the Swami, who "gave sincere and reassuring testimonials", as France's

86 Lardinois, L'invention de l'Inde, 164 and 197.

87 Maud Lallement, Swami Siddheswarananda et son temps: Tomes I, II \& III (Nantes: éditions du Petit Véhicule, 2006-2007).

88 Lallement, Swami Siddheswarananda: Tome II, 21.

89 Lallement, Swami Siddheswarananda: Tome II, 21-22.

90 Lallement, Swami Siddheswarananda: Tome II, 95-98. 
"best lawyer" and thanked him. Unexpectedly taking a political stance, he then emphasized the strength of will in France to accompany Asia on the path of independence as long as Asia "agrees to be carried along in safety and in respect for the ties that bind her to us." ${ }^{91}$ For his part, Masson-Oursel entreated the Swami to stay in France "to show what a pure, holy, just, and selfless man can achieve", and also implicitly referred to the current political situation while hoping for "mutual respect."92 Taking a less political tone, Renou justified the presence of the Swami on the occasion of the first lecture given by the latter in November 1947 in the following terms: "the Institute of Indian Civilization looks for everything which may enlarge its horizons and for every genuine teaching [. . .]." Then added: "We seek to make room for the living tradition, for the classical Vedanta as well as the modern," edging the contribution which the modern pandits might make to Indian studies.

\section{Common Features in the Field of Discourses on India}

My aim here has been to identify, through the study of Masson-Oursel's relations with non-hegemonic currents, the points of agreement and bones of contention which marked the broad field of discourses on India at that period. It is now time to come to some general conclusions on the matter. The principal bone of contention was, as expected, the level of consideration to be given to history and philology. On the question of the mutual agreements, I perceive three shared features across the writings of Masson-Oursel, some other academics and certain non-hegemonic currents: (1) the adopting of a critical attitude towards scholarly and philology-oriented Indology, (2) an interest in indigenous perspectives, (3) the high aspirations which they invested in their writings.

(1) Dissatisfaction with scholarly and philology-oriented Indology appears to be the most obvious element shared by Masson-Oursel and non-hegemonic currents. Masson-Oursel aimed to arrive at a deeper understanding of Hindu traditions, a goal which in his opinion had not been achieved by Indology. His

91 Lallement, Swami Siddheswarananda: Tome II, 96-97.

92 Lallement, Swami Siddheswarananda: Tome II, 98.

93 Lallement, Swami Siddheswarananda: Tome II, 108. 
criticism especially focused on the lack of sympathy towards the Indian religious way of thinking, and this criticism was shared by people located outside the academy, such as Herbert, Guénon and Monod-Herzen.

(2) Masson-Oursel's criticism is obviously linked to his own perspective towards Indology. What might be called the indigenous or insider perspective towards religion appealed to him. He firmly believed that commentary from modern Hindu philosophers can assist in coming to an understanding of Hindu sacred writings and herein also lies the reason for his interest in Guénon's assessments. In addition to his appeal towards the idea of a primordial knowledge, Guénon's theories resonated with Masson-Oursel because they appeared to embrace the notion of "judging the Hindu matter in an Indian way." A speech delivered by Masson-Oursel at Geneva in 1949 during the Rencontres internationales de Genève is particularly instructive in this regard. To the question: "Is it easier to understand religious otherness if we are ourselves a religious person?” Masson-Oursel provided the following answer:

\begin{abstract}
... When seeking to understand a non-European, human reality, the advantages of cultivating a sympathetic attitude towards and informing ourselves on religious matters far outweigh the disadvantages [...] There are people whose intelligence of religions is heightened, arising from the fact that religion is not confined to words [. . .] when we foolishly consider religion to be of no relevance, spiritual facts, inherently spiritual facts, remain unintelligible. It is better to understand the latter badly while according them meaning, than to grasp them in linguistic terms alone without discovering their meaning: a gesture of pure poverty. Jean Herbert knows this well, and he has often protested against such a mentality. Certain men whose knowledge should make them great Indologists or sinologists, on the pretext that they are not interested in magic or the power of the spirit - two different expressions for the same thing - limit themselves ultimately to a mere grammatical knowledge without arriving at the meaning of the text. ${ }^{94}$
\end{abstract}

Masson-Oursel, as I pointed it out, devoted himself to the spiritual life: believing that his devotion facilitated a better understanding of Indian religions, he took inspiration from the spiritually engaged perspective from which representatives of Neo-Hinduism or esoteric spokespersons addressed Hindu texts. His position however was not uncommon in the scholarly field. Here is not the place to enter into a discussion on the religionism/reductionism debate which shook the field of the study of religions, ${ }^{95}$ neither will I detail Masson-

94 Paul Masson-Oursel, "L'homme des Civilisations Orientales," in Pour un nouvel humanisme, textes des conférences et des entretiens organisés par les Rencontres internationales de Genève (Neuchâtel: éditions de la Baconnière, 1949), 75.

95 For an overview of this debate - which "is principally concerned with defining the proper method for the academic study of religion" - with a special emphasis on Western esotericism, 
Oursel's participation in the Eranos meetings. ${ }^{96}$ I will instead limit myself to two remarks. First, there is no inconsistency between Masson-Oursel's attraction towards the insider perspective and his program of comparative philosophy, which is decidedly etic in orientation. As indicated, Masson-Oursel was pursuing the same objective in both: to understand the spiritual phenomenon, to grasp its meaning and even its reality. They were both possible "means of realizing the spiritual" to use his own words as he expressed them at Eranos. ${ }^{97}$ Second, if such an objective accorded with Eranos's religionist perspective and "the project of exploring historical sources in search of what is eternal and universal," 98 Masson-Oursel never sacrificed historical evidence, ${ }^{99}$ and his position is better understood in comparison with that of other French Indologists, such as Renou and Lévi. For instance, in an enthusiastic review of a book on Japanese Buddhism written by a Japanese Buddhist, Sylvain Lévi wrote:

Religion, foreign to reason and science, cannot be explained by reason and science only; it is the work of the heart more than of the spirit, and must be appreciated through the heart more than through the spirit. Reading the sacred texts is not enough to gain an understanding of them; we must also love them with the fervour of a devotee, while also being ready to love other beliefs with equal fervour.

[. . .] The history of religions, to be exact and faithful, should resort to patient erudition as well to intuition; it is at the same time a science and an art. ${ }^{100}$

Through these assertions, Lévi implicitly referred to the overly positivist German Indology he firmly criticized. ${ }^{101}$ Naturally, similar claims to an intimate understanding of Indian religion were expressed by non-academic authors like Herbert,

see Wouter J. Hanegraaff, "Empirical Method in the Study of Esotericism," Method \& Theory in the Study of Religion 7, no.2 (1995): 99-129.

96 He participated several times in the Eranos meetings. His lectures delivered on the 1936 edition were issued in Joseph Campbell, ed., The Mysteries: Papers from the Eranos Yearbooks (London: Routledge, 1955).

97 Paul Masson-Oursel, "The Indian theories of Redemption in the Frame of the Religions of Salvation," in (ed.), The Mysteries: Papers from the Eranos Yearbooks, ed. Joseph Campbell, 3.

98 Hanegraaff, Esotericism and the Academy, 296.

99 And in this respect, he found himself closer to Gershom Scholem (1897-1982) than Henry Corbin, two leading figures of the Eranos meetings.

100 Sylvain Lévi, review of Le Bouddhisme Japonais, by Ryauon Fujishima, Revue critique d'histoire et de littérature, no. 52 (29 décembre 1890): 497-499.

101 Pascale Rabault, "Sylvain Lévi, lecteur de l'indianisme allemand: Comptes rendus parus dans la Revue Critique d'histoire et de littérature (1885-1914),” in Sylvain Lévi (1863-1935): études indiennes, histoire sociale, ed. Lune Bansat-Boudon and Roland Lardinois (Turnhout: Brepols, 2007), 301-342. 
Monod-Herzen and Guénon; however, from Masson-Oursel's perspective, as well as that of Lévi or Renou, such an understanding by necessity included philological erudition and historical criticism, a prerequisite unambiguously articulated in Masson-Oursel's program of comparative philosophy.

(3) Another striking feature of comparative philosophy is the high aspirations which Masson-Oursel invested in his program. In his auto-obituary, Masson-Oursel claimed: "There will be peace between human beings, in all the diversity of their societies, only once a less rigid and more generalized perspective of comparative study has emerged which will enable them to interact without either hatred or indifference."102 Masson-Oursel truly believed comparative philosophy can further the cause of peace through its cultivating of a keener appreciation of human thought and otherness. "Comparative philosophy is a necessary condition not only for peace, but for human existence itself" was his creed. ${ }^{103}$ If he was glad to have had an albeit limited influence within the academic circles, one can assume that he aspired to make a wider impact. The scope of influence of non-hegemonic currents sharing similar goals would thereby have represented a major force of attraction for him. Some of these currents also believed that a deeper understanding of Indian wisdom may play a role in building World peace and in aiding the recovery of the "materialistic" West. This is clearly expressed in the first edition of the periodical Spiritualite, which "proposes precisely to achieve the triumph of spirit over matter, love over hatred, through the synthesis of the overwhelmingly scientific Western culture with the spirituality of the East [...]." "104 Krur for its part regretted that this Western world, "whose limit is matter," "does not know light". ${ }^{105}$ This must be understood within the historical and cultural context of the first half of the twentieth century, deeply affected by the two world wars, the process of decolonisation and permeated by an atmosphere of crisis relating to the decline of the West and its forms of rationality. The collective book directed by Jacques Masui and published in 1949, Approches de l'Inde: Tradition et incidences, ${ }^{106}$ also provides a good example of such an atmosphere which I cannot discuss it in detail here.

102 Lacombe, "Paul Masson-Oursel (1882-1956)," 20.

103 Paul Masson-Oursel, "True philosophy is comparative philosophy," trans. Harold E. McCarthy, Philosophy East and West: A Quarterly Journal of Oriental and Comparative Thought 1, no.1 (April 1951): 8.

104 “Editorial," Spiritualité, no.1 (15 December 1944): 1.

105 “Introduzione: 'Volontà di Avanti,"” in Introduzione alla Magia quale scienza dell'Io (Roma: Tilopa Editrice, 1929), 1.

106 Jacques Masui, ed., Approches de l'Inde: Tradition et incidences (Paris: Les Cahiers du Sud, 1949). 
This book included articles written by scholars, such as Masson-Oursel, his student Olivier Lacombe, and Mircea Eliade, alongside others written by “prophets”, namely René Guénon, Jean Herbert and Sri Aurobindo. Furthermore, its opening epigraph is a quote from René Guénon: “ . . . if anything from the West can be saved, it will be with the help of the East ..." This epigraph echoes what Masson-Oursel wrote to the Swami Siddheswarananda in an unpublished letter dated 3 January 1940: "If it were to widen its field of influence, an apostolate like yours would restore to the Westerners their human dignity."107 Masson-Oursel was not the only academic Indologist who held this view. Alfred Foucher entertained the same expectations in the non-academic periodical France-Asie. In an article on Sri Aurobindo, he praised him while asking whether:

The problem is currently the same for all: will humanity allow itself to descend into a barbarity, precariously based on a combination of interests and avidities, or will the human race, faithful to its vocation and listening to the teachings of its wise men, make the necessary efforts to unite itself at a higher level of civilization? ${ }^{108}$

\section{Further Issues}

Although the focus here has been on Masson-Oursel, it then appears that he was not the only French Indologist to share certain viewpoints with nonhegemonic currents. Nevertheless, the depth of his relations with esoteric circles, which can schematically be perceived as located at the extremes of non-hegemonic currents, were quite remarkable for an academic Indologist of the time. I have yet to find any article by either Lévi or Renou in periodicals such as Krur or Spiritualité. Thus, the features I specified appear to be insufficient to explain Masson-Oursel's involvement in esoteric periodicals. His publicly acknowledged personal interest, as mentioned earlier, in areas related to esoteric currents -although not exclusively- may further explain this close relationship. Renou and Lévi do not, for their part, provide us with any public declaration of that kind. While Masson-Oursel, especially towards the end of his life, was seemingly not fazed by the controversial nature of these areas: Lévi and Renou, may simply not have had any interest in them, or alternatively

107 Correspondence from Paul Masson-Oursel to Swami Siddheswarananda, (3 January 1940, unpublished letter transmitted to the author at the courtesy of Alejandro Gutierrez), 2p.

108 Alfred Foucher, "Shrî Aurobindo," France-Asie 4, no. 59 (April 1951): 1193. 
could perhaps not bring themselves to public acknowledge such an interest. ${ }^{109} \mathrm{I}$ can do no justice to such an interrogation within the confines of the present article. Similarly, the interpretations of Hinduism given by Neo-Hinduist representatives, or even esoteric spokespersons, may have had an influence on the understanding of Hindu traditions by academic scholars such as Masson-Oursel or Renou; however, this must be discussed in more detail by specialists in Indian studies. ${ }^{110}$ I have sought in this article merely to highlight some features common to the broad field of Indology. To a certain extent, there can be a common ground between what may be called the academic, the non-hegemonic and the esoteric. Common perspectives and aspirations can be shared by each side and, in my opinion, this common ground needs to be clarified before getting into an analysis of their relationships and mutual influences in the various fields of human societies. This approach can indeed be applied to other fields, such as the medical one, on which my thesis, dealing with the practice of and discourse on medical holism in France during the interwar period, is focused.

\section{Bibliography}

Accart, Xavier. Guénon ou le renversement des clartés. Milan: Archè, 2005.

—_. “'Le Groupe Winter' entre perspective 'traditionnelle' et expérimentation médicale.”

Politica Hermetica. Ésotérisme et guérison, no.18 (2005): 98-108.

Asprem, Egil. The Problem of Disenchantment: Scientific Naturalism and Esoteric Discourse

1900-1930. Leiden: Brill, 2014.

109 In an instructive article in which he spoke in favour of the help modern pandits can bring to Indology while criticising esoteric currents, Renou asserted : "it is hoped that we will arrive at a stage in which it will no longer be possible to write general histories of philosophy without mentioning the philosophers of India; manuals of alchemy or astrology (like the two, excellent by the way, which have just appeared in the French collection “Que sais-je?”) leave out the considerable contribution of India in these matters to which Berthelot or Biot once knew how to ensure justice." See Louis Renou, "L'indianisme en 1952," Diogène, no.2 (April 1953): 90. It should be noted that the manual of astrology he referred to was highly critical, which was not the case of the one dealing with alchemy.

Sylvain Lévi for his part was a reader and supporter of the periodical Atlantis directed by the esotericist Paul le Cour (1871-1954).

110 Another very important chapter in the life of Paul Masson-Oursel which I did not have time to discuss here was his involvement in the field of psychology and more precisely applied psychology. On that matter, see the informative article focused on Masson-Oursel by Ana Freire, "Le fait psychique total au carrefour de la psychologie et de la psychagogie,” Academia, accessed 20 June 2018, https://www.academia.edu/15670540/LE_FAIT_PSYCHIQUE_TOTAL_AU_ CARREFOUR_DE_LA_PSYCHOLOGIE_ET_DE_LA_PSYCHAGOGIE 
Bagchee, Joydeep, and Vishwa P. Adluri. "The passion of Paul Hacker: Indology, orientalism, and evangelism." In Transcultural Encounters between Germany and India, edited by Joanne Miyang Cho, Eric Kurlander and Douglas T. McGetchin, 215-229. New York: Routledge, 2014.

Bisson, David. René Guénon : Une politique de l'esprit. Paris: Pierre-Guillaume de Roux, 2013. Bogdan, Henrik, and Olav Hammer. "Introduction." In Western Esotericism in Scandinavia, edited by Henrik Bogdan and Olav Hammer, 1-10. Boston: Brill, 2016.

Campbell, Joseph, ed. The Mysteries: Papers from the Eranos Yearbooks. London: Routledge, 1955.

François Chenet, François. “Du sens de la philosophie comparée.” In Philosophie comparée. Grèce, Inde, Chine, edited by Joachim Lacrosse, 79-98. Paris: Vrin, 2005.

De Giorgio, Guido. L'Instant et l'Eternité. Milan: Archè, 1987.

“Editorial.” Spiritualité, no.1 (15 December 1944): 1.

Eliade, Mircea. Fragments d'un journal I, 1945-1969. Paris: Gallimard, 1973.

Evola, Julius. UR \& KRUR [“Introduction à la magie"] UR 1927. Translated by Gérard Boulanger. Milano: Archè, 1983.

Filliozat, Jean and Louis Renou. L'Inde classique: Manuel des études indiennes. Paris: Payot, 1947.

Foucher, Alfred. "Shrî Aurobindo." France-Asie 4, no. 59 (April 1951): 1191-1193.

Freire, Ana. "Le fait psychique total au carrefour de la psychologie et de la psychologie." Academia, accessed 20 June 2018. https://www.academia.edu/15670540/LE_FAIT_ PSYCHIQUE_TOTAL_AU_CARREFOUR_DE_LA_PSYCHOLOGIE_ET_DE_LA_PSYCHAGOGIE

Guénon, René. René Guénon to Guido De Giorgio, 12 October 1924. http://www.index-reneguenon.org/

Hacker, Paul. "Aspects of Neo-Hinduism as Contrasted with Surviving Traditional Hinduism." In Paul Hacker: Kleine Schriften, edited by Lambert Schmithausen, 580-608. Wiesbaden: Franz Steiner Verlag GMBH, 1978.

Hakl, Hans Thomas. “Julius Evola and the UR Group.” Aries 12, no.1 (2012): 53-90.

Halbfass, Wilhelm. Philology and Confrontation: Paul Hacker on Traditional and Modern Vedanta. Albany: State University of New York Press, 1995.

—_ "Research and Reflection: Responses to my Respondents." In Beyond Orientalism: The Work of Wilhelm Halbass and its Impact on Indian and Cross-Cultural Studies, edited by Eli Franco and Karin Preisendanz, 297-314. Poznan studies in the philosophy of the sciences and the humanities, vol. 59, Amsterdam: Rodopi, 1997.

Hanegraaff, Wouter Jacobus. "Empirical Method in the Study of Esotericism." Method \& Theory in the Study of Religion 7, no.2 (1995): 99-129.

_- ed. Dictionary of Gnosis \& Western Esotericism. In collaboration with Antoine Faivre, Roelof van den Broek and Jean-Pierre Brach. Leiden/Boston: Brill, 2006.

- Esotericism and the Academy: Rejected Knowledge in Western Culture. Cambridge: Cambridge University Press, 2014.

Harlass, Ulrich. "Another Neo-Hinduism? The Reception of Theosophy in the South Indian Journal the Siddhanta Deepika." Journal of Hindu Studies 10, no.2 (2017): 164-186.

Henry and Stella Corbin fonds, 5 COR 273, École Pratique des Hautes Études Manuscripts and Archives - Religious Sciences section, Paris, France. 
Herbert, Jean. “Notes sur la Philosophie contemporaine de l'Inde." Le Lotus bleu 49, no.2 (April 1938): 33-49.

__. "La Mission de l'Indianisme Français." Les Cahiers du Sud (1 April 1944): 304-306.

__. "Indianisme d'après-guerre en Sorbonne." Le Lotus bleu 55, no. 9-10 (NovemberDecember 1950): 359-376.

“Introduzione: 'Volontà di Avanti.'” in Introduzione alla Magia quale scienza dell'lo, 1-5. Roma: Tilopa Editrice, 1929.

Johnson, William J. A Dictionary of Hinduism. New-York: Oxford University Press, 2009.

Lacombe, Olivier. “Paul Masson-Oursel (1882-1956)." In Ecole pratique des hautes études, Section des sciences religieuses, Annuaire 1957-1958, 19-23. Paris: Imprimerie Nationale, 1957.

Lallement, Maud. Swami Siddheswarananda et son temps, Tomes I, II \& III. Nantes: éditions du Petit Véhicule, 2006-2007.

Lardinois, Roland. L'invention de l'Inde: Entre ésotérisme et science. Paris: CNRS Editions, 2007.

- Scholars and Prophets: Sociology of India from France $19^{\text {th }}-20^{\text {th }}$ Centuries. New Delhi: Social Science Press, 2013.

Laurant, Jean-Pierre. René Guénon: Les enjeux d'une lecture. Paris: éditions Dervy, 2006.

Lévi, Sylvain. Review of Le Bouddhisme Japonais, by Ryauon Fujishima. Revue critique d'histoire et de littérature, no. 52 (29 décembre 1890): 497-499.

Masson-Oursel, Paul. "Objet et méthode de la philosophie comparée." Revue de métaphysique et de morale 19, no. 4 (July 1911): 541-548.

__ . "Doctrines et méthodes psychologiques de l'Inde." Journal de psychologie normale et pathologique, 1921: 529-547.

—. Review of Introduction générale à l'étude des doctrines hindoues, by René Guénon. Scientia 31 (1922): 411.

—. La philosophie comparée. Paris: Alcan, 1923.

—. Esquisse d'une histoire de la philosophie indienne. Paris: Geuthner, 1923.

- Review of L'homme après la mort, edited by Fernand Divoire. Mercure de France (1st October 1927): 153.

- Review of Le Roi du monde, by René Guénon. Revue critique d'histoire et de literature, no.20 (15 October 1927): 399.

__. "La Libération à l'indienne." Cahiers de l'Étoile, no.12 (May-June 1929): 405-416.

__. "Sul ruolo della magia nella speculazione indù." In Introduzione alla Magia quale scienza dell'lo, 259-264. Roma: Tilopa Editrice, 1929.

__. "La psychologie contemporaine et l'Intelligence de la Pensée Indienne." Revue Théosophique, no.4 (June 1935): 122-125.

—. Paul Masson-Oursel to Swami Siddheswarananda. Unpublished letter, Paris, 3 April 1939.

—. Paul Masson-Oursel to Swami Siddheswarananda. Unpublished letter, Paris, 3 January 1940.

—_. "Lecture delivered by Mr Masson-Oursel for the 105th birthday of the birth of Ramakrishna." Retranscription, Saint-Mandé, 25 February 1940.

- Introduction to Le pressentiment chrétien dans les religions anciennes, by Emile Lesimple, 7-8. Paris: Adrien Maisonneuve, 1942.

__. "L'Indianisme français contemporain." Revue de l'histoire des religions 126 (1943): $57-62$. 
__ "Identité de la physique et de la psychologie dans la philosophie indienne." Spiritualité

9, no.16 (15 March 1946): 90-91.

—_. "Le signe de l'homme." Le Signe de l'Homme, no.1 (October 1946): 8-9.

—_. "La méditation asiatique et la psychanalyse." Psyché, no.1 (November 1946): 68-70.

—_. "Comment l'Inde se représente l'âme humaine ou l'esprit humain." Harmonie, no.1 (January 1949): 7-9.

__. "L'homme des Civilisations Orientales." In Pour un nouvel humanisme, textes des conférences et des entretiens organisés par les Rencontres internationales de Genève, 69-93. Neuchâtel: éditions de la Baconnière, 1949.

—. Introduction to Amulettes, talismans \& pantacles, by Jean Marquès-Rivière, 5-6. Paris: Payot, 1950.

—_. "True philosophy is comparative philosophy." Translated by Harold E. McCarthy. Philosophy East and West: A Quarterly Journal of Oriental and Comparative Thought 1, no.1 (April 1951): 6-9.

_- "Lumières de la Raison : Profondeurs de la Conscience." Revue Métapsychique, no.15 (July-August 1951): 97-98.

__. "La connaissance scientifique de l'Asie en France depuis 1900 et les variétés de l'orientalisme." Revue philosophique de la France et de l'étranger (1953): 342-358.

—. "The Indian theories of Redemption in the Frame of the Religions of Salvation." In The Mysteries: Papers from the Eranos Yearbooks, edited by Joseph Campbell, 3-8. London: Routledge, 1955.

—. Introduction to Disciplines, ritualisme et spiritualité, by René Fouéré, 9-10. Paris: éditions du vieux colombier, 1960.

—_. Introduction to De la psychanalyse à l'astrologie, by André Barbault, 7. Paris: Seuil, 1961.

__. "Sur le role de la magie dans la speculation hindoue." In Tous les écrits de Ur \& Krur (1927 - 1928-1929): Introduction à la Magie (1955), 297-305. Milano: Archè, 1986.

Masui, Jacques, ed. Approches de l'Inde: Tradition et incidences. Paris: Les Cahiers du Sud, 1949.

Monod-Herzen, Gabriel. Shri Aurobindo. Paris: Les Cahiers du Sud, 1954.

Moore, Charles A., ed. Philosophy - East and West, 2nd ed. Princeton: Princeton University Press, 1946.

Herbert, Jean. "Orient de l'âme: Entretien avec Jean Herbert: Interview with Jean Herbert." By Nouvelle Clés. Nouvelles Clés 22 (1992): 19-28.

Paul Masson-Oursel file, documents waiting for inventory, Sorbonne Interuniversity Library Archives, Paris, France.

Rabault, Pascale. "Sylvain Lévi, lecteur de l'indianisme allemand: Comptes rendus parus dans la Revue Critique d'histoire et de littérature (1885-1914)." In Sylvain Lévi (1863-1935). études indiennes, histoire sociale, edited by Lune Bansat-Boudon and Roland Lardinois, 301-342. Turnhout: Brepols, 2007.

Renou, Louis. “L'indianisme en 1952.” Diogène, no.2 (April 1953): 80-95.

Rolland, Romain. Gandhi. Paris: Stock, 1924.

—. Essai sur la mystique et l'action de l'Inde vivante. Paris: Stock, 1929. . Vie de Ramakrishna. Paris: Stock, 1929.

—. Vie de Vivekananda. Paris: Stock, 1930.

Santucci, James A. “Theosophical Society.” In Dictionary of Gnosis \& Western Esotericism, edited by Wouter J. Hanegraaff, Antoine Faivre, Roelof van den Broek and Jean-Pierre Brach, 1114-1123. Leiden/Boston: Brill, 2006. 
Sedgwick, Mark. Against the Modern World: Traditionalism and the Secret Intellectual History of the Twentieth Century. Oxford/New York: Oxford University Press, 2004.

Servais, Paul. “Jean Herbert (1897-1980) et l'art de la traduction." In Passeurs de religions entre Orient et Occident, edited by Jacques Scheuer and Paul Servais, 193-203. Louvainla-Neuve: Bruylant-Academia, 2004.

Viswanathan, Gauri. “Theosophical Society." In Brill's Encyclopedia of Hinduism. Vol. 5, edited by Knut A. Jacobsen, Helene Basu, Angelika Malinar, and Vasudha Narayanan, 678-688. Leiden/Boston: Brill, 2013. 